Polónyi Eszter M.

\title{
A magyar filmipar, Balázs Béla és a háború utáni pillanat - Szekfü András interjúgyújteménye
}

\section{Szerző}

Eszter Polonyi is a Visiting Assistant Professor at the History of Art and Design Department of the Pratt Institute where she works on the histories of film and photography.

https://doi.org/10.31176/apertura.2019.14.4.8 


\section{Polónyi Eszter M.}

\section{A magyar filmipar, Balázs Béla és a háború utáni pillanat - Szekfü András interjúgyújteménye}

[Szekfü András: Így filmeztünk. Válogatás fél érszázad magyar filmtörténeti interjúiból. Budapest, MMA Kiadó, 2018.]

Az elbeszélt történelem [oral history] által lehetôvé válik egy bizonyos filmtörténeti írásmód. Az elbeszélt történelem az egyik legkevésbé megbízható információforrásra, az emberi emlékezetre támaszkodik. Más, rögzítésre alkalmas eszközökkel ellentétben az emberi emlékezet a deformálás önkényes formáinak veti alá a rögzített tartalmat. Míg a visszaemlékezéseket gyakran korrigálni lehet, egy adott eseménnyel kapcsolatos emlékeket idôvel asszociációk sûrú szövedéke veszi körül, kibillentve az interjúalanyt a pozícióból, melyból megszólalni kívánt. Gyakran nem is a megszólaló által felidézett emléktartalom érdekli a hallgatót, aki esetenként az események szinkrón, s nem lineáris rekonstruálásában közremúködô ismétlések, megbicsakló és téves emlékek mélyebb okait igyekszik feltárni. Ezért kérdőjelezheti meg az elbeszélt történelem a más módon létrejövố történeti beszámolókat. Az elbeszélt történelem módszereit korán elsajátító Szekfü András Így filmeztünk címú interjúkötetéből olyan képet kapunk, melyet egyetlen elsô- vagy másodkézbôl származó tanúvallomás sem tudna megidézni. Kevés módszer lenne alkalmasabb arra, hogy megragadja a közös múlt tizenkilenc különböző elbeszéléséból kirajzolódó társadalmi kötôdések és esztétikai elköteleződések folyton alakuló képét.

Szekfü abban az idôben kezdte készíteni az interjúkat, amikor az elbeszélt történelem gyakorlati szempontból épp elkezdett megvalósíthatóvá válni. Az elbeszélt történelem képviselôinek elsô generációjához tartozott, amikor beszerezte a Philips EL 3302 kézi és hordozható kazettás magnót, mellyel lecserélte a Grundig-szalagos magnót; ez utóbbinak a mérete egy kisebb hûtôszekrényével vetekedett. Valószínú hogy a hordozható Philips magnó jelentôsen kisebb méreteinek köszönhetố, hogy a készülék számos vallomást rögzíthetett. Az 1969 és 1971 között készített interjúk során Szekfü a második világháborút követố koalíciós idôszakról kérdezte alanyait, akik tehát a szovjet befolyásra 1949-ben létrejövô egypártrendszert megelôzó évekre mintegy 20 éves távlatból emlékeztek vissza; s bár ez hosszú idônek számít, mégsem jelentette azt, hogy büntetlenül lehetett beszélni. Bizonyos értelemben talán csak egy teljesen eltérô kérdezési szituáció és felvételi technológia árnyékában lehetne ezeket a tartalmakat felszínre hozni (,....ez olyan, mintha vallatnál”, „Ez tényleg olyan”, 110). Freud úgy vélte, az ismétlésen keresztül tör felszínre az, amit elfelejtettünk.

Míg az Így filmeztünk egyes olvasóit meglepte az a látszólagos „ôszinteség”, mellyel egyik-másik 
interjúalany a korszakot kritizálta, véleményem szerint egyrészt fenntartással kell fogadnunk ezeket a szavakat, másrészt a kötet valódi értékét az interjúk kimondatlan, önkéntelen és elfojtott tartalmai adják.

Szekfü ismétlődô érdeklődése e kötetben Balázs Béla (1884-1949) és az 1945-ös visszatérését követô évek mélyebb megértésére irányul. Balázs visszatérése elvileg meghatározó eseménynek számíthatott volna. Ekkorra már megjelent két filmmúvészeti alapmúve (Der sichtbare Mensch, 1925, Der Geist des Films, 1930), a húszas és a harmincas években pedig német, illetve orosz nyelvterületeken elôadásokat tartott, elismerték tanácsadói, kritikusi és elméletírói tevékenységét. Filmes területen szerzett írói, oktatói és elméleti tapasztalatai révén Balázs valami újat tudott nyújtani a magyar filmiparnak, mégpedig egy filmesztétikai diszkurzus intézményi és konceptuális alapjait. Még ha Balázs fent említett írásait nem is fordították magyarra az 1950-es évek végéig, magyarországi jelenléte megerôsítette a háborús évek alatt magyarul megjelent filmmel kapcsolatos gyakorlati, tudományos és elméleti munkákat (Hevesy Iván: $A$ film életrajza, 1943.; Kertész Pál: Filmáru és filmmúvészet, 1943.; Kispéter Miklós: A gyözelmes film, 1938.; Fejér Tamás: Film. A film gyártása, esztétikája, és jövöje, 1943.; Dáloky János: Így készül a magyar film, 1942.; valamint Pudovkin magyarul 1944-ben megjelent múve, $A$ film technikája).

Szekfü beszélgetései számos részlettel gazdagítják tudásunkat Balázs utolsó éveirôl, terveirôl, valamint azokról az emberekról, akikkel ekkoriban kapcsolatban állt. Megtudhatjuk, hogy írásai már visszatérése elôtt alapmúveknek számítottak (Herskó János és Újhelyi Szilárd). A legtöbben - s nem meglepố módon, fốként kritikusai - elismerik tekintélyét. Emlékeznek arra, hogy a felvételi bizottság tagja volt a föiskolán (229), hogy fôiskolai bizottsági tagként dolgozott (55), részt vett pártvetítéseken (155), elôadásokat tartott (például az „Árt-e a múveltség a színésznek” címú elôadássorozat is a nevéhez fúződik, 133, valamint 53), számos filmes produkcióban múködött közre tanácsadóként, mindenekelōtt Szőts és Radványi mellett (29, 113, 116). Már a húszas évek elején megfogalmazott terveivel összhangban a filmtudománynak és filmrestaurálásnak szentelt intézmény (Filmtudományi Intézet) alapításába kezdett, valamint filmes és múvészeti heti folyóiratot (Fényszóró) is indított azzal a nem titkolt szándékkal, hogy támogatókat gyưjtsön maga köré. 


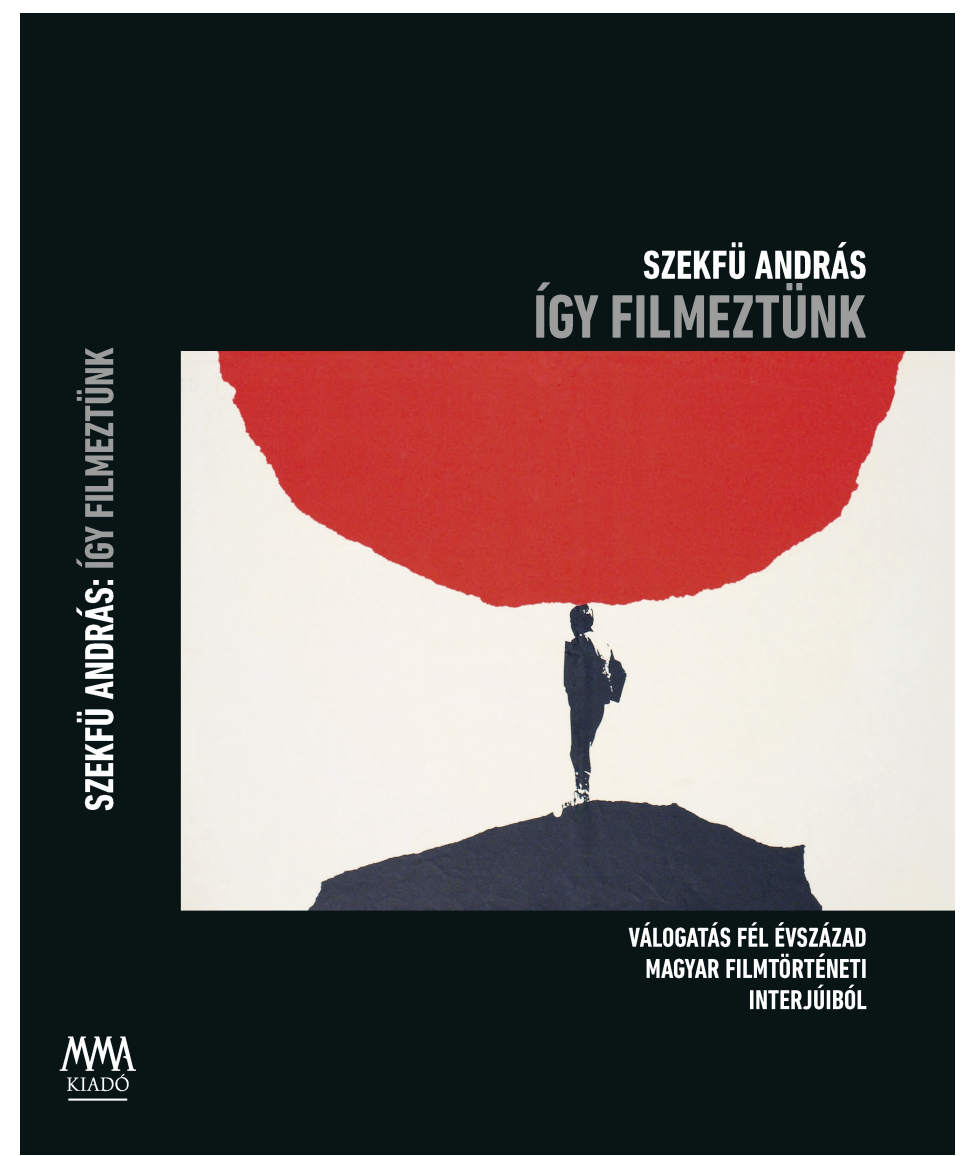

Szekfü András: Így filmeztünk. Válogatás fél érszázad magyar

filmtörténeti interjúiból

Mégis minden arról tanúskodik, hogy Balázs erôfeszítéseit egyre kevesebb siker koronázta. Elismertsége ekkor már leáldozóban volt, hazai projektjei pedig rendre megbuktak. Folyóiratát elôször csak szüneteltették, majd végleg leállították. Terve, hogy a mai filmarchívum konceptuális kereteit (valamint fotó- és könyvgyújteményét) megalapozó Filmtudományi Intézetet hozzon létre végül nélküle valósult meg. Legtöbb filmötlete, melyek jelentôs része fellelhetô Balázs MTAhagyatékában, soha nem jutott messzebb a tervezóasztalnál. Még azok is, akik Balázs védelmére kelnek a kötetben, bizonyos fokú nevetségességrôl beszélnek vele kapcsolatban. Ranódy László például felidézi, hogyan mesélte el Balázs ,ától cettig” A látható ember tartalmát egy filmre váró közönség elôtt (53). Az is igaz - ezt Radványi fogalmazza meg -, hogy Balázsnak nem volt diplomáciai érzéke (116). Balázs viselkedése valóban hagyott némi kívánnivalót maga után, ha csak azt nézzük, hogy hány levelet írt különbözô kormányhivatalnokoknak. Ugyanakkor nincs akkora narcizmus, mely megmenthette volna attól az üldözési mániától, melyet az ellene forduló tanítványai idéztek elô (Ranódy meg is jegyzi, mennyire ironikus, hogy ugyanezek a tanítványok kapják meg néhány évvel késôbb a hôn áhított Balázs Béla-díjat, 54, lásd még 79 és 156). Nem mennénk olyan messzire, hogy azt állítsuk, Balázs korai (65 éves korában bekövetkezô) halálában szerepe volt az egyre inkább érezhetôvé váló kiközösítésnek; annyi azonban bizonyosnak túnik, hogy Balázs visszatérése olyan lehetôség volt, melyet a magyarok jobban is kihasználhattak volna. Létezik ugyanakkor egy másik magyarázat is a kudarcra, melyet érzésem szerint Szekfü módszere 
feltár. A film abban tér el leginkább más múvészeti formáktól, hogy nem egyetlen ember alkotása, hanem emberek és gépek közösen létrehozott produktuma. A munkássága alapos ismerete nélkül is világos, Balázs felismerte, hogy a film ipari gyártás eredménye. Amennyiben ezek az évek hozzájárultak korai halálához, ez azért volt, mert tudta, a magyar filmiparral kapcsolatos elképzelései, legyenek bármilyen ígéretesek is, nem érnek semmit az államgépezet támogatása nélkül. A továbbiakban arra igyekszem rámutatni, hogy ez a párhuzam film és államapparátus között Szekfü interjúiban is megjelenik.

Az interjúk során elbeszélt háború utáni évek különös filmtörténeti jelentôséggel bírnak. A film ebben az idôszakban válik a világ ezen táján azzá, amit a hetvenes évek filmelméleti diszkurzusa „filmként” határoz meg. Szekfü megszólaltatta a korabeli film számos vezetô alakját - Makk Károly kivételével senki nem végzett korábban filmes tanulmányokat (a filmrendezôk közül Ranódy László ügyvédnek, Radványi Géza újságírónak, Fábri Zoltán díszlettervezônek tanult; késôbb pedig tôlük tanulnak azok, akik már a filmiparban kezdik karrierjüket, mint például Máriássy Félix). A térség öt évtizedes filmgyártása ellenére Magyarországon 1945-ben alakult ki az elsố két iskola, amelyek tanították a filmkészítést és a filmrendezést. És Balázs beavatkozásáig egyetlen hivatalos archívum sem tette tanulmányozásra elérhetôvé a filmet. Csak néhány, kis költségvetéssel rendelkező stúdió üzemelt, akik rövid, határozott idejú szerződéssel foglalkoztatják az így hol itt, hol ott dolgozó alkalmazottakat. Mindez gyökeresen megváltozik a kötet által vizsgált öt év alatt. 1951-ben az ország már filmlaborok, stúdiók, szövetségek és oktatási intézmények központosított, a gyártást, forgalmazást és bemutatást irányító hálózatával rendelkezik. „Az extenzív fejlődés idôszaka volt ez - mondja az egyik interjúalany - [...] A játékfilmgyártást kellett elindítani, az üres mútermeket múvészekkel benépesíteni, és a másik kulcsfeladat: minden faluban mozi legyen" (Szántó Miklós, 172). A magyar filmgyártás intézményesítésének mértéke 1948 és 1951 között meghaladta a két háború között, a hangosfilm megjelenésének idôszakában bekövetkezô összeomlás és az azt követô konszolidáció nagyságrendjét. 
A filmkészítés professzionalizálódásából jelentôs mértékben profitált a film mint múvészetiforma. A negyvenes évek vége Nyugat-Európában és Észak-Amerikában szorosan összefonódikolyan jelentôs rendezốk megjelenésével, mint John Ford vagy Orson Welles. Ezeket a neveket az interjúalanyok is megemlítik, amikor a magyarországi helyzetrôl beszélnek (Ford esetében lásd 42, 43, Welles 205). Szekfü beszélgetôtársai szerint a háborút közvetlenül követô években változás következett be a filmmúvészet célját érintô elképzelésekben. „1945-tôl kezdve kezdôdtek a viták a múvészetrôl, ekkor kezdtek el foglalkozni az esztétikával”, mondja Máriássy Judit (133). Bár a rendezô esztétikai értelemben vett jelentôségét a kritikai diszkurzusban csak néhány évtizeddel késôbb teoretizálja a szerzôi mozgalom, Szekfü beszélgetôtársai már a negyvenes évek végén stiláris koherenciáról beszélnek, például Radványi Géza (Valahol Európában, 1947) vagy Szôts István( Ének a búzamezôkrôl, 1947) kapcsán, akiket a filmrendezéssel együtt járó irányítói és koordinációs kérdések egyaránt foglalkoztattak (lásd például Radványi anekdotáját arról, hogy egy stáb okozta frusztráció miatt vált rendezôvé, 110).

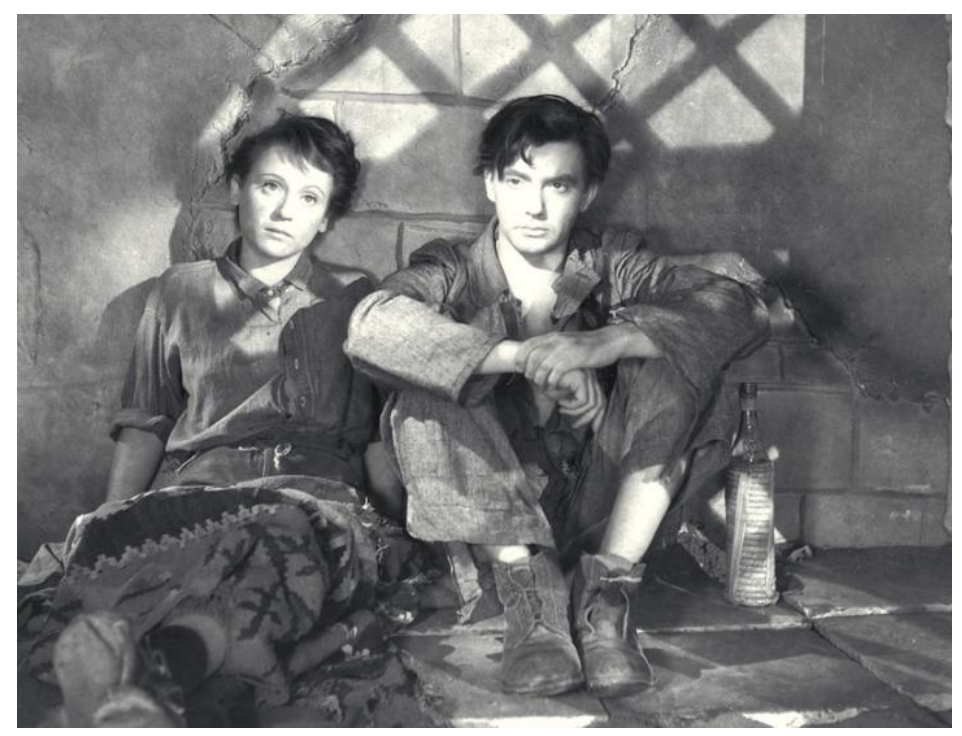

Valahol Európában (Radványi Géza, 1947)

Magyarországon olyan szempontból érdekes a helyzet, hogy a film mint ipar 1946 és 1951 közötti intézményesülése egybeesik a szocialista állam és a Rákosi-rendszer kiépülésével. Az 1948 áprilisában kezdôdô központosítás a filmipar állami kézbe kerülését, vagyis a filmipar irányításának az állami apparátusba történô beolvadását jelentette. A filmgyártáshoz kötôdô munka átszervezése, ahogyan arról az interjúalanyok is beszámolnak, nem okozhat különösebb meglepetést. Ugyanakkor fontos megemlíteni, hogy a magyarországi államosítástól függetlenül, a harmincas és negyvenes években mindenhol lezajlik egyfajta szakosodási és szabványosítási folyamat a filmkészítésben. És a két apparátus - állam és film - közötti bizonyos hasonlóságok a filmrendezôk és az államigazgatás tagjainak viselkedésében egyaránt megfigyelhetôk.

Szekfü vállalkozásának egyik legérdekesebb aspektusa, hogy kormányzati hivatalnokokat is megszólaltatott egy látszólag csak filmesekrôl és filmkészítésrôl szóló projekt kapcsán. Olyan emberekkel is beszélgetett, akik fél lábbal a filmiparban, fél lábbal pedig a politikában voltak 
érdekeltek. Készített interjút például filmgyárigazgatókkal, múvészeti vezetôvel (Angyal László, Révai Dezsố, Horváth Márton, Hont Ferenc), de oktatási intézmények vezetôivel is (Hont Ferenc), a múvelôdési minisztérium munkatársaival (Kende István, Szántó Miklós), sốt még a pártpolitika második legbefolyásosabb alakítójával is (Horváth Márton). Politikai befolyásuk ellenére feltételezhetô, hogy ezeket az embereket Szekfü olvasóinak jelentôs része nem ismeri név szerint. Mivel az állítólagos semlegesség garanciájának tekintették, az anonimitás a munka része volt.

Szekfü látszólag azért környékezi meg ezeket a pártembereket, hogy többet megtudjon a kommunista hatalomátvétel után rögtön bekövetkezô központosítás körülményeiről. A koalíciós évek alatt készült filmek közül több is tiltólistára került, és Szekfü igyekszik kideríteni ennek okait. A válaszokban rendre megjelennek a filmiparba érkező pártpolitikusok növekvő befolyására tett utalások. A filmesek a hatalmi pozícióba került embereket hibáztatják, különösen Hontot, Révai Dezsốt és Révai Józsefet. De amikor Szekfü velük beszélget, például Honttal, akkor azt tapasztaljuk, hogy ezek az emberek saját jelentôségüket igyekeznek, így vagy úgy, tompítani. Az, hogy Horváth többes szám elsô személyben beszél, arról tanúskodik, hogy nyelvében igyekszik szisztematikusan hárítani. Révai József - a tagadás klasszikus taktikáját alkalmazva - az egyetemes logikára és értelemre hivatkozva fogalmazza meg kifogásait (lásd a Máriássy Judit által elbeszélt esetet, 140). De leggyakrabban mégis arra hivatkoznak az érintettek, hogy nem állt módjukban befolyásolni a történéseket, hiszen a valódi döntéshozatal más, irányításuk alá nem tartozó szinteken történt. Ez a felelősséghárítás jelenik meg többek között Révai Dezsô és Hont Ferenc esetében, akik másokra mutogatással indokolják a Balázst ért méltatlan bánásmódot (a Balázst és Filmkultúra címú könyvét érô szovjet kritikákat hibáztatják, illetve magát Balázst, aki szerintük túlérzékeny, „nyomasztó” és „öreg” volt). Ezek az emberek látszólag mindenféle elfogultság, érdek vagy tudatosság nélkül cselekedtek, pusztán a hivatalos protokollt képviselték.

A szerzői film egyik jellegzetessége a szerzőiség folytonos kimozdításában rejlik. Szőts például így vall arról, hogy miként igyekezett a technikai stáb javaslatait figyelembe venni: „Mindig tökéletes összhangban [kellett múködnünk]... ha [az operatôrnek] voltak jobb elképzelései, jobb beállítási szögei, akkor voltam annyira okos én is, hogy nem ragaszkodtam a magaméhoz." (25) A szerzôrendező a stáb tudására is hagyatkozik, hiszen újszerú megközelítésük alapját a kollektív gyártási mód jelenti. Mégis, jelenlétük éppen csak érezhetô, ahogyan Truffaut fogalmaz, olyan, mint a „hômérséklet”. A szerzô, aki a stábbal közösen kialakított, kézjegyként múködô stílus révén adja el filmjeiket, kicsit az állami cenzorhoz hasonlít, aki soha nem érzi saját hatalma súlyát.

A filmipar válaszúton áll, amikor Balázs visszatér Magyarországra. Ahogy az egyik pártfunkcionárius elmondja Szekfünek, a filmgyártás ekkor két különböző irányba indulhatott volna. Az 1948-as Talpalatnyi földre, az államosított magyar filmgyártás elsô filmjére utalva, Kende István megjegyzi, hogy „körülbelül 1948-49-ig a Valahol Európában túnt a reprezentatív filmnek, de a korra, amirôl beszélünk [1949-51], az a jellemző hogy a Talpalatnyi föld vette át a szerepét, és szerintem teljes joggal” (170). Ez az idônként bizonytalankodó, önmagát javító vagy éppen humoros, s közben valamiféle történelmi igazságot makacsul kutató interjúkötet azt szemlélteti, hogy volt egy olyan pillanat a háború utáni magyarországi filmgyártás történetében, amikor a 
szocialista-realista rigor mortis gyors bekövetkezése még nem tûnt elkerülhetetlennek.

Fordította Karácsonyi Judit

[A szerzó által autorizált fordítás.] 
(c) Apertúra, 2019. nyár | www.apertura.hu

webcím: https://www.apertura.hu/2019/nyar/polonyi-a-magyar-filmipar-balazs-bela-es-a-haboru-

utani-pillanat-szekfu-andras-interjugyujtemenye/

https://doi.org/10.31176/apertura.2019.14.4.8

(Q)opertúro 